\title{
PERANAN SUBSEKTOR PERIKANAN DALAM MENUNJANG PEREKONOMIAN KABUPATEN KAMPAR PROVINSI RIAU
}

\author{
Tibrani \\ Fakultas Pertanian Universitas Islam Riau Jl. Kaharuddin Nasution No. 113 Pekanbaru. 28284, Riau \\ Telp: 0761-674681; Fax: 0761-674681
}

\begin{abstract}
ABSTRAK
Kabupaten Kampar memiliki potensi perikanan yang cukup besar dan ditetapkan sebagai sentra produksi perikanan budidaya di Propinsi Riau. Produksi perikanan Kampar tahun 2014 sebanyak 54.984,58 ton dengan nilai sebesar 867.040,77 juta rupiah. Penelitian ini bertujuan untuk menganalisis : (1) Kontribusi Subsektor perikanan Terhadap Pendapatan Domestik Regional Bruto (PDRB) Kabupaten Kampar; (2) Kedudukan atau Tingkat Basis dan Non Basis Ekonomi Subsektor perikanan dalam Pembangunan Wilayah Kabupaten Kampar dan; (3) Multiplier Effect Subsektor perikanan terhadap PDRB wilayah dan kesempatan kerja Kabupaten Kampar. Hasil penelitian menunjukkan bahwa kontribusi sektor perikanan Kabupaten Kampar pada tahun 2011 terhadap PDRB (tanpa migas) ke tahun 2012 terjadi peningkatan yang signifikan dan pada tahun 2013 dan tahun 2014 relatif berkurang namun masih diatas $16 \%$. Sedangkan kontribusi sektor perikanan terhadap tenaga kerja berkisar antara 2,63 sampai 2,95\% dengan rata-rata sebesar 2,78 \%. Selama periode tahun 2011-2014 sektor perikanan merupakan sektor basis dalam perekonomian wilayah Kabupaten Kampar berdasarkan indikator pendapatan wilayah (PDRB) dengan nilai LQ dengan kisaran nilai LQ 2,32 - 4,90 dengan rata-rata 4,16. Selama periode tahun 2010-2013 sektor perikanan memberikan efek penggandaan (Multiflier Effect) yang cukup berarti bagi pertumbuhan ekonomi wilayah Kabupaten Kampar. Nilai Multiflier Effect rata-rata sebesar 8,56 pada indikator pendapatan wilayah dan berdasarkan indikator angkatan kerja nilai Multiflier Effect rata-rata sebesar 29,37.
\end{abstract}

Kata Kunci: Subsektor perikanan, Multiplayer efek, Analisis Shift share dan Location Quotien

\section{PENDAHULUAN}

Peranan sub-sektor perikanan dalam pembangunan nasional yang utama adalah menghasilkan bahan pangan protein hawani, mendorong pertumbuhan agroindustri, sumber devisa melalui peningkatan ekspor hasil perikanan, menciptakan lapangan kerja, peningkatan pendapatan dan kesejahteraan petani ikan dan nelayan serta menunjang pembangunan daerah. Sejalan dengan hal tersebut maka kebijaksanaan umum pembangunan sub-sektor perikanan di Provinsi Riau berorientasi pada peningkatan produktivitas, nilai tambah, perluasan lapangan kerja dan efesiensi usaha serta peningkatan pendapatan usaha perikanan.

Pembangunan perikanan Provinsi Riau pada hakekatnya merupakan bagian integral dari pembangunan nasional dan daerah dengan fokus utamanya menjadikan manusia perikanan yang berkualitas dan berproduktivitas tinggi melalui proses pembangunan terpadu dan berkelanjutan. Strategi pembangunan perikanan yang diterapkan adalah pembangunan agribisnis perikanan secara terpadu, berkelanjutan yang mencirikan usaha ekonomi perikanan yang tangguh, mandiri dan berakar di pedesaan.

206 I Peranan Subsektor Perikanan Dalam Menunjang Perekonomian Kabupaten Kampar Provinsi Riau 
Salah satu indikator kemajuan pembangunan dan kesejahteraan masyarakat di suatu wilayah adalah Produk Domestik Regional Bruto (PDRB) per kapita yang menggambarkan besarnya pendapatan rata-rata yang mungkin dicapai masyarakat. Oleh karena itu, upaya meningkatkan peranan dan kontribusi suatu sektor terhadap PDRB maupun PDRB per kapita terus dilakukan, diantaranya melalui optimalisasi pada sektor antara lain komoditas yang belum dimanfaatkan secara optimal.

Ditinjau dari perekonomian daerah, Kabupaten Kampar didukung oleh sektor perdagangan dan pertanian utamanya sub sektor perikanan air tawar. Nilai PDRB (menurut harga berlaku) pada tahun 2014 sebesar 15.008.232,9 juta rupiah dengan tingkat pertumbuhan ekonomi sebesar 3,21 persen pertahun. Kabupaten Kampar memiliki potensi perikanan yang cukup besar berupa sumbangan produksi dari sub-sektor perikanan tangkap, budidaya, dan pengolahan, sumbangan perikanan tersebut yaitu sebanyak 54.984,58 ton dengan nilai produksi sebesar 867.040,77 juta rupiah pada tahun 2014. Selain itu dari pengolahan ikan juga memberikan sumbangan terhadap peningkatan perekonomian di Kabupaten Kampar. Pengolahan tersebut sebahagian besar dari produksi perikanan perairan umum. Selain itu dari sektor budidaya perikanan juga memberikan sumbangan terhadap perekonomian di Kabupaten Kampar baik budidaya kolam dan keramba (Statistik Perikanan Dinas Perikanan dan Kelautan Kabupaten Kampar, 2015). Dengan Karakteristik wilayah yang dimiliki Kabupaten Kampar serta kebijakan yang mendukung, maka sub sektor perikanan sudah seharusnya menjadi sub sektor yang dapat memberikan kontribusi yang baik terhadap perekonomian di Kabupaten Kampar khususnya dari segi pendapatan. Menurut Tarigan (2004), satu-satunya sektor yang dapat meningkatkan perekonomian wilayah melebihi pertumbuhan alamiah adalah sektor basis.

Suatu sektor jika digolongkan sebagai sektor basis ekonomi di suatu daerah, maka sektor tersebut mampu berswasembada dalam memenuhi kebutuhan konsumsi daerah dan menghasilkan surplus untuk ekspor keluar daerah dan pertumbuhannya menciptakan efek penggandaan (multiplier effect) yang pada akhirnya akan meningkatkan pendapatan daerah secara keseluruhan serta memacu pertumbuhan sektor-sektor lain, sehingga penelitian ini bertujuan untuk menganalisis peranan subsektor perikanan dalam menunjang perekonomian Kabupaten Kampar Provinsi Riau.

\section{METODELOGI PENELITIAN}

Metode yang digunakan dalam penelitian ini adalah metode analisis data sekunder yang dilaksanakan di Kabupaten Kampar Provinsi Riau pada bulan Desember 2015. Penentuan lokasi dilakukan secara sengaja (purposive), dengan pertimbangan Kabupaten Kampar ditetapkan sebagai sentra produksi perikanan air tawar di Propinsi Riau serta memiliki potensi perikanan yang cukup besar untuk dikembangkan.

207 I Peranan Subsektor Perikanan Dalam Menunjang Perekonomian Kabupaten Kampar Provinsi Riau 
Data yang dikumpulkan dalam penelitian ini adalah data rangkaian waktu (time series data) mulai dari 2010-2014, melalui: Data Dinas Perikanan dan Kelautan Kabupaten Kampar, Badan Pusat Statistik (BPS) Kabupaten Kampar. Data sekunder yang dimaksud meliputi : (1) Keadaan geografis, Jumlah dan Kepadatan Penduduk, (2) Tingkat pendidikan dan Mata Pencaharian penduduk Kabupaten Kampar, (3) Perkembangan tenaga kerja, (4) Perkembangan Produksi Perikanan Kabupaten Kampar, (5) Perkembanagn PDRB Kabupaten Kampar, (6) Perkembangan PDRB Provinsi Riau.

\section{Batasan Penelitian}

Batasan penelitian ini hanya untuk mengetahui peranan sub-sektor perikanan dalam menunjang perekonomian wilayah Kabupaten Kampar, apakah subsektor perikanan tergolong ke dalam sektor basis atau non basis.

\section{Analisis Data}

\section{Analisis Shift Share}

Analisis ini bertujuan untuk mengetahui kontribusi sub-sektor perikanan terhadap PDRB dan tenaga kerja (Sawano dan Endang dalam Sianturi, 2004) dengan model matematis :

$$
\mathrm{Ki}=\frac{V i}{P i} \times 100 \%
$$

Keterangan :

$\mathrm{Ki}=$ Besarnya kontribusi sub-sektor perikanan dalam tahun $i$.

$V i=$ PDRB sub-sektor perikanan pada tahun $i$ atau jumlah tenaga kerja sektor perikanan pada tahun $i$.

$P i=$ Total PDRB tahun $i$ atau total tenaga kerja seluruh sektor pada tahun $i$.

Kriteria nilai Shift share yaitu semakin besar nilai Shift share, maka kontribusi sektor sub-sektor perikanan terhadap PDRB atau kesempatan kerja semakin besar.

\section{Analisis Location Quotient (LQ)}

Analisis ini bertujuan untuk mengetahui tingkat basis sub-sektor perikanan dalam pembangunan wilayah berdasarkan tingkat indikator PDRB atau tenaga kerja (Tarigan dalam Sianturi, 2004) secara matematis :

$\mathrm{LQ}=\left(\frac{v i / V i}{v t / V t}\right)$

Keterangan :

$\mathrm{LQ}=$ Location Quotient

208 | Peranan Subsektor Perikanan Dalam Menunjang Perekonomian Kabupaten Kampar Provinsi Riau 
$v i=$ Pendapatan sub-sektor perikanan (PDRB sub-sektor perikanan) atau jumlah tenaga kerja subsektor perikanan di Kabupaten Kampar.

$V i=$ Total PDRB Kabupaten Kampar atau total tenaga kerja seluruh sektor di Kabupaten Kampar.

$v t=$ PDRB sub-sektor perikanan atau jumlah tenaga kerja sub-sektor perikanan Provinsi Riau.

$V t=$ Total PDRB Provinsi Riau atau total tenaga kerja seluruh sektor di Provinsi Riau.

Kriteria penentuan sektor basis yaitu jika nilai LQ lebih besar dari 1 maka, suatu sektor merupakan sektor basis dan jika nilai LQ lebih kecil dari 1maka, suatu sektor merupakan sektor nonbasis.

\section{Analisis Multiplier Effect (Efek Berganda)}

Analisis ini digunakan untuk mengetahui keterkaitan antara sub sub-sektor perikanan dengan sektor lainnya atau dengan kata lain untuk melihat dampak sub-sektor perikanan terhadap pembangunan wilayah berdasarkan indikator pendapatan wilayah/tenaga kerja (Glasson, 1978). Dengan model matematiknya :

$\mathrm{M}=\frac{\Delta Y}{\Delta P}$

Keterangan :

$\mathrm{M}=$ Nilai Penggandaan Jangka Pendek.

$\Delta Y=$ Perubahan Nilai Tambah PDRB Atau Tenaga Kerja Seluruh Sektor Di Wilayah Kampar (PDRB Atau Jumlah Tenaga Kerja Tahun Ke-I Diukur PDRB Atau Jumlah Tenaga Kerja Tahun Sebelumnya).

$\Delta \mathrm{P}=$ Perubahan Nilai Tambah PDRB Sub-Sektor Perikanan Atau Tenaga Kerja Seluruh SubSektor Perikanan Di Wilayah Kabupaten Kampar (PDRB Atau Jumlah Tenaga Kerja Tahun ke-I Dikurang PDRB Atau Jumlah Tenaga Kerja Tahun Sebelumnya).

Kriteria dari Multiplier Effect yaitu jika nilai $\mathrm{M}=\mathrm{X}$, berarti setiap nilai tambah yang dihasilkan pada sub-sektor perikanan sebesar 1,00 rupiah, maka akan terjadi peningkatan terhadap nilai tambah wilayah sebesar X rupiah dan kriteria nilai Multiplier Effect terhadap tenaga kerja yaitu jika nilai $\mathrm{M}=$ $\mathrm{X}$, berartai setiap peningkatan angkatan kerja yang dihasilkan pada sub-sektor perikanan sebesar 1 orang maka akan terjadi peningkatan angkatan kerja wilayah sebesar X orang.

\section{HASIL DAN PEMBAHASAN}

Kontribusi Sub-sektor Perikanan Terhadap Pendapatan Domestik Regional Bruto (PDRB) Kabupaten Kampar

Pembangunan suatu daerah tidak terlepas dari peranan sektor-sektor yang menyusun perekonomian suatu wilayah. Berikut ini akan dibahas peranan sektor perikanan dalam pembangunan daerah Kabupaten Kampar Provinsi Riau.

209 | Peranan Subsektor Perikanan Dalam Menunjang Perekonomian Kabupaten Kampar Provinsi Riau 


\section{Kontribusi Sektor Perikanan Terhadap PDRB (Analisis Shift Share)}

Analisis Shift Share menggambarkan besarnya kontribusi suatu sektor terhadap PDRB dan juga besarnya kontribusi angkatan kerja suatu sektor terhadap total angkatan kerja. Analisis Shift Share dapat dilihat berdasarkan indikator pendapatan wilayah dan indikator angkatan kerja. Analisis Shift Share digunakan untuk mengetahui proses pertumbuhan ekonomi suatu daerah dalam kaitannya dengan perekonomian daerah acuan yaitu wilayah yang lebih luas, dalam hal ini adalah wilayah Kabupaten Kampar dikaitkan dengan Provinsi Riau.

Untuk mengetahui proses pertumbuhan ekonomi suatu daerah dengan menggunakan analisis Shift Share digunakan variabel penting seperti tenaga kerja dan pendapatan wilayah. Dalam penelitian ini digunakan variabel pendapatan wilayah yaitu PDRB dan variabel tenaga kerja untuk menguraikan pertumbuhan ekonomi Kabupaten Kampar. Kontribusi masing-masing sektor dalam PDRB disajikan dalam Tabel 1.

Berdasarkan Tabel 1 dapat dilihat bahwa kontribusi yang diberikan oleh sektor perikanan dalam pembangunan wilayah Kabupaten Kampar dari tahun 2011sampai 2014 mengalami peningkatan, dimana pada tahun 2011 sub-sektor perikanan menyumbang sebesar 3,42 persen naik menjadi 6,25 persen pada tahun 2014. Sektor pertanian, kehutanan dan perikanan sebagai penyumbang terbesra dalam PDRB Kabupaten Kampar di luar sektor pertambangan dan penggalian, dimana kontribusi sub-sektor perikanan dalam sektor pertanian, kehutanan dan perikanan adalah 28,31 persen.

Sub-sektor perikanan merupakan sub-sektor penyumbang terbesar terhadap PDRB Kabupaten Kampar dibandingkan dengan sektor lain pada periode 2011-2014. Sub-sektor perikanan kontribusinya selalu mengalami peningkatan setiap tahunnya, namun pada tahun 2014 mengalami penurunan tetapi besar tidaklah berarti yaitu dari 6,36\% tahun 2013 menjadi 6,25\% tahun 2014.

\section{Kontribusi Sektor Perikanan terhadap Angkatan Kerja (Analisis Shift Share)}

Penyediaan lapangan kerja untuk angkatan kerja merupakan salah satu tujuan dari pembangunan nasional, kontribusi sektor perikanan terhadap angkatan kerja di Kabupaten Kampar Tahun 20112014 dilihat pada Tabel 2.

Tabel 1. Kontribusi Sektor Ekonomi Menurut Lapangan Usaha Terhadap PDRB Kabupaten Kampar, Tahun 2011-2014

\begin{tabular}{llrrrr}
\hline \multirow{2}{*}{ No } & \multicolumn{1}{c}{ Lapangan Usaha } & \multicolumn{4}{c}{ Tahun } \\
\cline { 3 - 6 } & & 2011 & 2012 & 2013 & \multicolumn{1}{c}{2014} \\
\hline 1. & Pertanian, Kehutanan dan & 25,97 & 24,05 & 22,38 & 22,08 \\
& Perikanan & $(3,42)$ & $(3,19)$ & $(6,36)$ & $(6,25)$ \\
2. & Pertambangan dan Penggalian & 40,30 & 42,72 & 45,91 & 46,80 \\
3 & Industri Pengolahan & 21,78 & 21,03 & 19,65 & 18,71 \\
4. & Pengadaan Listrik dan Gas & 0,04 & 0,04 & 0,03 & 0,05 \\
\hline
\end{tabular}

210 | Peranan Subsektor Perikanan Dalam Menunjang Perekonomian Kabupaten Kampar Provinsi Riau 


\begin{tabular}{llrrrr}
\hline \multirow{2}{*}{ No Lapangan Usaha } & \multicolumn{5}{c}{ Tahun } \\
\cline { 3 - 6 } & \multicolumn{1}{c}{2011} & 2012 & 2013 & 2014 \\
\hline 5. & Pengadaan Air, Pengelolaan Sampah, Limbah & 0,01 & 0,01 & 0,01 & 0,01 \\
& dan Daur Ulang & & & & \\
6. & Konstruksi & 4,98 & 5,43 & 5,53 & 5,65 \\
7. & Perdagangan Besar dan Eceran, Reparasi & 2,62 & 2,61 & 2,54 & 2,83 \\
& Mobil dan Sepeda Motor & & & & \\
8. & Transportasi dan Pergudangan & 0,26 & 0,25 & 0,23 & 0,23 \\
9. & Penyediaan Akomodasi dan Makan Minum & 0,08 & 0,07 & 0,07 & 0,07 \\
\hline 10 & Informasi dan Komunikasi & 0,38 & 0,36 & 0,34 & 0,33 \\
11. Jasa Keuanga dan Asuransi & 0,38 & 0,35 & 0,35 & 0,33 \\
12. & Real Estate & 0,83 & 0,82 & 0,80 & 0,81 \\
13. Jasa Perusahaan & 0,00 & 0,00 & 0,00 & 0,00 \\
14. & Administrasi Pemerintahaan, Pertahanan dan & 1,54 & 1,49 & 1,42 & 1,38 \\
& Jaminan Sosial & & & & \\
15. & Jasa Pendidikan & 0,46 & 0,42 & 0,39 & 0,38 \\
16 & Jasa Kesehatan dan Kegiatan Sosial & 0,14 & 0,13 & 0,13 & 0,13 \\
17. & Jasa Lainnya & 0,23 & 0,21 & 0,21 & 0,21 \\
\hline & PDRB & $\mathbf{1 0 0 , 0 0}$ & $\mathbf{1 0 0 , 0 0}$ & $\mathbf{1 0 0 , 0 0}$ & $\mathbf{1 0 0 , 0 0}$ \\
\hline
\end{tabular}

Sumber : Kabupaten Kampar Dalam Angka (2015)

Tabel 2. Kontribusi Sektor Perikanan Kabupaten Kampar Terhadap Tenaga Kerja, Tahun 20102014.

\begin{tabular}{ccccc}
\hline No & Tahun & RTP & Tenaga Kerja & Kontribusi (\%) \\
\hline 1 & 2010 & 11.318 & 207.658 & 5,45 \\
2 & 2011 & 11.318 & 213.370 & 5,31 \\
3 & 2012 & 16.256 & 220.051 & 7,39 \\
4 & 2013 & 14.034 & 226.012 & 6,21 \\
\hline 5 & 2014 & 11.606 & 231.951 & 5,01 \\
\hline
\end{tabular}

Sumber : Kabupaten Kampar 2015

Berdasarkan Tabel 2 dapat dilihat bahwa kontribusi yang diberikan oleh sektor perikanan terhadap tenaga kerja dari tahun 2010 sampai ke tahun 2014 mengalami fluktuasi dari tahun ke tahun, terjadinya fluktuasi ini kemungkinan disebabkan karena usaha perikanan yang dilakukan penduduk tidak hanya usaha budidaya tetapi juga penangkapan ikan di perairan umum yaitu di sungai dan di danau. Disebabkan karena hasil tangkapan sudah mulai berkurang, maka mereka mengalihkan usaha di luar usaha perikanan. Kontribusi sub-sektor perikanan dalam menyerap tenaga kerja yang paling tinggi pada tahun 2012 dan tahun 2014, masing-masing sebesar 7,39\% dan 6,21 persen.

Kedudukan Atau Tingkat Basis dan Non-Basis Ekonomi Sub-sektor perikanan dalam Pembangunan Wilayah Kabupaten Kampar

211 I Peranan Subsektor Perikanan Dalam Menunjang Perekonomian Kabupaten Kampar Provinsi Riau 
Laju pertumbuhan suatu wilayah ditentukan oleh besarnya peningkatan ekspor dari wilayah tersebut. Kegiatan ekonomi dikelompokkan atas kegiatan basis dan non basis. Hanya kegiatan basis yang mendorong pertumbuhan ekonomi wilayah. Analisis basis dan non basis pada umumnya didasarkan atas nilai tambah maupun lapangan kerja.

Untuk mengetahui basis atau non basis suatu sektor pada perekonomian suatu wilayah dapat menggunakan analisis Location Quotien (LQ), dimana nilai LQ tersebut merupakan rasio antara peranan masing-masing sektor di Kabupaten Kampar dengan peranan sektor tersebut di Provinsi Riau. Kriterianya adalah :

1. Bila LQ>1 menunjukkan sektor tersebut tergolong sektor basis di suatu daerah.

2. Bila LQ<1 menunjukkan sektor tersebut tergolong sektor non basis di suatu daerah.

3. Bila LQ=1 menunjukkan keswasembadaan (self-sufficiency) sektor tersebut dan tergolong non basis di suatu daerah.

Analisis ini digunakan untuk mengidentifikasi potensi internal yang dimiliki suatu daerah yaitu sektor-sektor mana yang merupakan sektor basis (basic sector) dan sektor mana yang bukan sektor basis (non basicsector). Pada dasarnya analisis ini menyajikan perbandingan relatif antara kemampuan satu sektor antara daerah yang diselidiki dengan kemampuan sektor yang sama pada daerah yang lebih luas (Warpani 1984).

Analisis basis ekonomi pada sektor perikanan berdasarkan indikator LQ dapat diperoleh dari perbandingan relatif kemampuan sektor perikanan di Kabupaten Kampar dengan di tingkat Provinsi Riau. Nilai LQ tersebut menggambarkan tingkat basis sektor perikanan Kabupaten Kampar berdasarkan indikator pendapatan wilayah (Tarigan, 2004). Nilai LQ sektor perikanan Kabupaten Kampar berdasarkan indikator PDRB disajikan pada Tabel 3.

Pada Tabel 3 dapat dilihat bahwa sektor perikanan dari tahun 2011 sampai 2014 merupakan sektor basis ekonomi di Kabupaten Kampar hal ini terjadi karna sektor perikanan telah menghasilkan surplus dan potensi untuk dapat dipasarkan ke luar daerah serta ekspor. Perhitungan LQ sektor perikanan Kabupaten Kampar menunjukkan hasil yang tinggi dengan rata-rata 3,67 dengan nilai tertinggi 5,09 dan terendah 1,76.

\section{Multiplier Effect Sub-sektor Perikanan Terhadap PDRB Wilayah Dan Kesempatan Kerja Kabupaten Kampar}

Perhitungan Multiflier Effect hanya dapat dilakukan pada sektor basis saja, karna sektor basis yang dapat menimbulkan efek penggandaan terhadap perekonomian secara keseluruhan. Pemikiran dasar konsep ini adalah pertumbuhan pendapatan dalam wilayah terjadi karna penggandaan jumlah oleh adanya pembelanjaan kembali (dalam wilayah) pendapatan dari barang dan jasa yang diproduksi

212 | Peranan Subsektor Perikanan Dalam Menunjang Perekonomian Kabupaten Kampar Provinsi Riau 
di dalam wilayah dan dipasarkan keluar wilayah. Oleh karena sektor perikanan di Kabupaten Kampar tergolong basis maka digunakan analisis Multiflier Effect. Untuk melihat Multiflier Effect sektorperikanan dapat menggunakan indikator PDRB dan dapat menggunakan indikator Angkatan kerja.

\section{Analisis Multiflier Effect Berdasarkan Indikator PDRB}

Perhitungan Multiflier Effect sektor perikanan berdasarkan indikator PDRB merupakan rasio atau perbandingan antara total PDRB dengan PDRB sektor perikanan di Kabupaten Kampar. disajikan pada Tabel 4.

PadaTabel 4 dapat diketahui bahwa nilai Multiflier Effect pada tahun 2014 sebesar 32,58 berarti bahwa setiap peningkatan nilai tambah yang dihasilkan pada sektor perikanan sebesar 1,00 rupiah maka akan terjadi peningkatan terhadap nilai tambah wilayah Kabupaten Kampar sebesar 32,58 rupiah.

Tabel 3. Location Quotien Sektor Perikanan Kabupaten Kampar Berdasarkam PDRB Seri 2010 Atas Dasar Harga Berlaku Menurut Kategori Tanpa Migas Tahun 2011-2014 (Juta Rupiah)

\begin{tabular}{ccccccc}
\hline Tahun & $\begin{array}{c}\text { vi } \\
\text { (juta Rp) }\end{array}$ & $\begin{array}{c}\text { Vi } \\
\text { (juta Rp) }\end{array}$ & $\begin{array}{c}\text { Vt } \\
\text { (juta Rp) }\end{array}$ & $\begin{array}{c}\text { Vt } \\
\text { (juta Rp) }\end{array}$ & LQ & $\begin{array}{c}\text { Basis/non } \\
\text { Basis }\end{array}$ \\
\hline 2011 & $410.886,00$ & $31.222 .644,30$ & $2.352 .182,34$ & $314.119 .415,27$ & 1,76 & Basis \\
2012 & $867.040,54$ & $34.589 .247,30$ & $2.535 .607,12$ & $344.350 .764,00$ & 3,40 & Basis \\
2013 & $889.288,15$ & $37.521 .341,40$ & $1.732 .428,08$ & $372.046 .950,84$ & 5,09 & Basis \\
\hline 2014 & $937.040,08$ & $41.395 .209,50$ & $2.234 .094,45$ & $436.989 .740,46$ & 4,43 & Basis
\end{tabular}

Sumber : BPS Kabupaten Kampar (data diolah)

Tabel 4. Multiflier Effect Sektor Perikanan Kabupaten Kampar Berdasarkan PDRB Atas Harga Konstan Tahun 2000, Tahun 2011-2014 (Juta Rupiah)

\begin{tabular}{|c|c|c|c|c|c|c|}
\hline No & Tahun & $\mathrm{Y}$ & $\mathrm{P}$ & $\Delta \mathrm{Y}$ & $\Delta \mathrm{P}$ & $\mathrm{M}$ \\
\hline 1. & 2011 & $29.787 .397,7$ & $410.886,00$ & - & - & - \\
\hline 2. & 2012 & $31.932 .910,8$ & $867.040,54$ & $2.145 .513,10$ & 456.154 .54 & 4,70 \\
\hline 3. & 2013 & $34.100 .744,9$ & $889.288,15$ & $2.167 .834,10$ & $22.247,61$ & 97,44 \\
\hline 4. & 2014 & $35.656 .463,5$ & $937.040,08$ & $1.555 .718,60$ & $47.751,93$ & 32,58 \\
\hline
\end{tabular}

Sumber : BPS Kabupaten Kampar (data diolah)

Pada tahun 2013 nilai Multiflier Effect sektor perikanan berdasarkan indikator pendapatan wilayah sebesar 97,44 dan pada tahun 2012 nilainya hanya 4,70 hal ini disebabkan karena nilai produksi ikan pada periode tersebut memang rendah.

\section{Analisis Multiflier Effect berdasarkan Indikator Angkatan Kerja}

213 | Peranan Subsektor Perikanan Dalam Menunjang Perekonomian Kabupaten Kampar Provinsi Riau 
Multiflier Effect sektor basis dengan indikator Angkatan kerja adalah untuk melihat dampak perluasan kesempatan kerja dalam suatu wilayah yang terjadi akibat adanya perubahan tenaga kerja yang bekerja di sektor perikanan. (Anwar dan Santoso, 1985). Perhitungan nilai Multiflier effect sektor perikanan di Kabupaten Kampar berdasarkan indikator angkatan kerja disajikan pada Tabel 5.

Berdasarkan Tabel 5 diketahui bahwa nilai Multiflier Effect angkatan kerja sektor perikanan pada tahun 2011 sebesar 1,35 ini berarti bahwa dengan pertambahan satu orang tenaga kerja pada sektor perikanan maka akan menciptakan kesempatan kerja di Kabupaten Kampar sebesar 1,35 jiwa. Pada tahun 2013 dan tahun 2014 Multiflier Effect sektor perikanan bernilai negatif terhadap angkatan kerja masing-masing sebesar $-2,68$ dan $-2,45$, hal ini mengidikasikan bahwa telah terjadi alih profesi dari usaha perikanan ke usaha lain.

Tabel 5. Multiflier Effect Sektor Perikanan Kabupaten Kampar Berdasarkam Indikator Angkatan Kerja, Tahun 2011-2014

\begin{tabular}{cccccrr}
\hline No & Tahun & $\mathrm{Y}$ & $\mathrm{P}$ & $\Delta \mathrm{Y}$ & $\Delta \mathrm{P}$ & \multicolumn{1}{c}{$\mathrm{M}$} \\
\hline 1. & 2011 & 213.370 & 11.318 & - & - & - \\
2. & 2012 & 220.051 & 16.256 & 6.681 & 4.938 & 1,35 \\
3. & 2013 & 226.012 & 14.034 & 5.961 & -2.222 & $-2,68$ \\
\hline 4. & 2014 & 231.951 & 11.606 & 5.939 & -2.428 & $-2,45$ \\
\hline
\end{tabular}

Sumber : BPS Kabupaten Kampar (data diolah)

\section{KESIMPULAN DAN SARAN}

\section{Kesimpulan}

1. Kontribusi sektor perikanan Kabupaten Kampar pada tahun 2011 terhadap PDRB (tanpa migas) ke tahun 2012 terjadi peningkatan yang significan dan pada tahun 2013 dan tahun 2014 relatif berkurang namun masih diatas $16 \%$. Sedangkan kontribusi sektor perikanan terhadap tenaga kerja berkisar antara 2,63 sampai 2,95\% dengan rata-rata sebesar 2,78 \%.

2. Selama periode tahun 2011-2014 sektor perikanan merupakan sektor basis dalam perekonomian wilayah Kabupaten Kampar berdasarkan indikator pendapatan wilayah (PDRB) dengan nilai LQ dengan kisaran nilai LQ 2,32 - 4,90 dengan rata-rata 4,16.

3. Selama periode tahun 2010-2014 sektor perikanan memberikan efek penggandaan (Multiflier Effect) yang cukup berarti bagi pertumbuhan ekonomi wilayah Kabupaten Kampar. Nilai Multiflier Effect rata-rata sebesar 8,56 pada indikator pendapatan wilayah dan indikator angkatan kerja nilai Multiflier Effect rata-rata sebesar 29,37.

Saran

214 I Peranan Subsektor Perikanan Dalam Menunjang Perekonomian Kabupaten Kampar Provinsi Riau 
1. Karena sektor perikanan merupakan sektor basis dalam perekonomian wilayah Kabupaten Kampar diharapkan kepada pemerintah maupun dinas terkait untuk memprioritaskan pengembangan sektor perikanan dalam pembangunan ekonomi di Kabupaten Kampar.

2. Untuk mengembangkan sektor perikanan, sebaiknya pemerintah daerah dapat menarik minat para investor untuk menanamkan modal dalam usaha perikanan.

\section{DAFTAR PUSTAKA}

Adisasmita, R. 2005. Dasar-dasar Ekonomi Wilayah. Graha Ilmu. Yogyakarta.

Anwar, E dan Santoso, H. 1985. Zona Wahana Komunikasi Ilmu-Ilmu Pembangunan Wilayah. HIIPIPWI.Bogor.

Arsyad, L. 1999. Pengantar Perencanaan dan Pengembangan Daerah. Yogyakarta. BPFE.

Badan Pusat Statistik Kabupaten Kampar. 2015. Kampar Dalam Angka 2015. Badan Pusat Statistik Kabupaten Kampar.

Blair, J.P. 1991. Urban and Regional Economics. Irwin, Hometone.

Boediono.1999. Teori Pertumbuhan Ekonomi. Yogyakarta: BPFE

Budiman, A. 1996. Teori Pembangunan Dunia Ke Tiga. Lembaga Penerbit Fakultas Ekonomi Universitas Indonesia. Jakarta : PT. Gramedia Pustaka Utama.

Dinas Perikanan dan Kelautan Kabupaten Kampar. 2015. Laporan Tahunan Dinas Perikanan dan Kelautan Kabupaten Kampar Tahun 2015.

Effendi, I. 2004. Pengantar Akuakultur. Penebar Swadaya. Jakarta.

Ghalib, R. 2005. Ekonomi Regional. Pustaka Ramadhan. Bandung.

Glasson, J. 1977. Pengantar Perencanaan Regional. Jakarta : LPFEUI.

Glasson. 1978. Pengantar Perencanaan Regional (Terjemahan). Jakarta : LPFEUI. 172 Hal.

Glasson. 1990. Pengantar Perencanaan Regional. Terjemahan Paul Sitohang. Jakarta: LPFEUI.

Iwan. N. dan Rochmin, D. 2004. Pembangunan Wilayah. Pustaka LP3ES Indonesia. Jakarta.

Kadariah, 1985. Ekonomi Perencanaan. Lembaga Penelitian Fakultas Ekonomi Universita Indonesia Jakarta. Jakarta.

Sianturi, E. H. P. 2004. Analisis Ekonomi Basis dan Sektor Perikanan Dalam Perekonomian Wilayah Provinsi Riau. Skripsi (Tidak dipublikasikan) Kampar : Universitas Riau, Fakultas Perikanan dan Ilmu Kelautan, Jurusan Sosial Ekonomi Perikanan.

Sukirno, S. 1978. Ekonomi Pembangunan Jakarta ; LPFEUI.

Sukirno, S. 1992. Pengantar Makro Ekonomi Edisi Kedua. PT. Radja Grafindo Persada. Jakarta.

215 | Peranan Subsektor Perikanan Dalam Menunjang Perekonomian Kabupaten Kampar Provinsi Riau 
Tarigan, R. 2004. Ekonomi Regional Teori dan Aplikasi. Bumi Aksara. Jakarta.

Tarigan, R. 2005. Ekonomi Regional: Teori dan Aplikasi. Edisi Revisi. Penerbit Bumi Aksara.

Todaro, Michael P dan Stephen C. Smith. 2003. Pembangunan Ekonomidi Dunia Ketiga. Edisi kedelapan. Jilid I. Penerbit Erlangga. Jakarta.

216 I Peranan Subsektor Perikanan Dalam Menunjang Perekonomian Kabupaten Kampar Provinsi Riau 
217 | Peranan Subsektor Perikanan Dalam Menunjang Perekonomian Kabupaten Kampar Provinsi Riau 